\title{
Relations between Normal Serum Gamma-glutamyltransferase and Risk Factors of Coronary Heart Diseases according to Age and Gender
}

Se Young Kwon and Young Ak Na

Department of Biomedical Laboratory Science, Daegu Health College, Daegu 41453, Korea

\section{연령과 성별에 따른 정상 혈청 Gamma-glutamyltransferase와 관상동맥질환 위험인자와의 관계}

\author{
권세영, 나영악 \\ 대구보건대학교 임상병리과
}

\begin{abstract}
Serum gamma-glutamyltransferase (GGT) has been widely used as a marker of alcohol intake and liver failure. Recently, the relativity between GGT and various diseases has been identified with growing interest. In this study, we examined relativity between GGT value and risk factors of coronary heart diseases among those with normal GGT value, excluding heavy drinkers. Specifically, we compared the differences based on age and gender. Data from the 2011 KNHNES were used $(\mathrm{N}=3,619)$. When the subjects were categorized according to quartile based on the serum GGT levels, there was 10 20, $21 \sim 27,28 \sim 38,39 \sim 71 \mathrm{IU} / \mathrm{L}$ in men, and 6 12, 13 16, 17 $\sim 22,23 \sim 42 \mathrm{IU} / \mathrm{L}$ in women. The mean of most variables was the highest in the $4^{\text {th }}$ quartile (Q4), however age and LDL Cholesterol were the highest in the $2^{\text {nd }}$ quartile $(Q 2)$ in men. The FRS and 10 -year CHD risk was the highest in the $2^{\text {nd }}$ quartile in men, and the highest in the $4^{\text {th }}$ quartile in women. Increased GGT was correspondingly linked with age in women but age was the highest in GGT in the $2^{\text {nd }}$ quartile in men. In the 70's, the highest Q1 and Q2 was in men and the highest Q3 and Q4 in women. Although GGT value was within the normal range, increased GGT showed correlation with various risk factors. The FRS and 10-year CHD risk showed different patterns according to age and gender along with increased GGT value.
\end{abstract}

Keywords: Gamma-glutamyltransferase, Framingham risk score, Coronary heart disease

This is an Open Access article distributed under the terms of the Creative Commons Attribution Non-Commercial License (http://creativecommons.org/licenses/by-nc/4.0) which permits unrestricted non-commercial use, distribution, and reproduction in any medium, provided the original work is properly cited.

Copyright (c) 2016 The Korean Society for Clinical Laboratory Science. All rights reserved.
Corresponding author: Se Young Kwon

Department of Biomedical Laboratory Science, Daegu Health College, Yeongsong-ro, Buk-gu, Daegu 41453, Korea

Tel: 82-53-320-1362

Fax: 82-53-320-1450

E-mail: sykwon@dhc.ac.kr

Received: January 29, 2016

Revised $1^{\text {st. }}$ : February 15, 2016

Revised 2 ${ }^{\text {nd }}:$ February 22, 2016

Accepted: February 23, 2016

\section{서 론}

혈중 gamma-glutamyltransferase (GGT)는 지금까지 간기능 장애와 대표적인 알코올 섭취 관련 지표로서 적은 비용으로도 정확 도와 민감도가 높은 검사로 폭넓게 사용되어 왔다[1,2]. 세포막에 분포하는 GGT는 세포 밖 글루타치온의 대사와 관련한 효소로[2],
최근 산화 스트레스와 관련한 연구들이 진행되면서[3] 이전의 알코 올 섭취와 간 손상의 지표뿐만 아니라 다양한 질환과 GGT 상승과 의 관계에 대한 연구가 활발히 진행되고 있다. 비 알코올성 지방간 환자에서도 GGT 수치의 상승이 증명되어 더 이상 알코올에 의존 적인 지표가 아니라 간세포 손상의 지표임이 확인되었고[4], 심혈 관 질환, 뇌졸중, 고혈압, 당뇨, 비만, 대사증후군과 같은 산화스트 
레스와 관련 있는 질환에서 꾸준히 그 상관관계가 입증되었다 [5-9]. 최근에는 신장질환과 관련한 상관성도 보고 되었다[10,11]. 한편 당뇨 관련 한 연구에서는 혈중 GGT의 상승 수준이 낮더라도 관련 질환 발생 위험도는 커지므로 GGT 수치의 낮은 증가도 의미 를 두기도 하였는데[12], 이렇듯 GGT 수치의 크고 작은 증가와 관 련하여 그 중요성을 강조하고 있다. 그러나 대부분의 연구에서 간 손상 관련 질환이나 간기능에 영향을 주는 약물 복용과 관련한 대 상자는 제외되어 있으나, 알코올 관련 요인은 제외 항목이 아니었 고 그 결과는 알코올 섭취 정도가 증가함에 따라 심혈관 질환, 고혈 압, 당뇨, 대사증후군 등 각종 질환과의 관련성이 더 크게 나타났다 [5-9]. 최근 국내에서 행해진 GGT 상승과 관련한 심혈관 질환과 고 혈압과의 상관성을 입증한 연구에서도 GGT 수치가 비정상 고농도 군이 포함되어 있으며[13,14], 정상범위의 GGT 수치를 대상으로 한 연구는 드문 실정이다.

따라서 본 연구에서는 고도의 음주군에 해당하는 대상자를 제외 하고 GGT 수치가 정상 범위에 속하는 대상자들에서 GGT 수치에 따른 관상동맥 질환 위험 요인과의 관련성을 살펴보고, 연령과 성 별에 따른 특성을 비교 검토하고자 하였다.

\section{재료 및 방법}

\section{1. 연구대상}

2011년 1월부터 12월까지 시행된 국민건강영양조사에서 총 대 상자 8,518명 중 30세 이상에서 GGT와 Framingham risk score (FRS) 계산 항목에서 결측치를 제외한 대상자는 4,680명이었다. 이 중에서 GGT 수치에 영향을 줄 수 있는 요인을 고려하여, B형 간염, C형 간염 그리고 간경변증으로 진단 받은 자 172 명, 간기능 검사 관 련 항목 수치가 정상범위를 벗어난(aspartate aminotransferase $[\mathrm{AST}] \geq 34$, alanine aminotransferase $[\mathrm{ALT}] \geq 3$, 남성: GGT $\geq$ 71, 여성: GGT 242)경우에 해당하는 대상자 798명, 그리고 음주 빈도 설문 항목에서 '거의 매일' 이라고 응답한 고위험 음주군 91 명 을 제외한 최종 연구 대상자 총 3,619명(남성 1,354명, 여성 2,265 명)에 대한 결과를 분석하였다. 본 연구는 질병관리본부 연구윤리 심의위원회의 승인을 받아 수행된 조사자료(승인번호: 201102CON-06-C)를 대상으로 분석을 시행하였다.

\section{2. 연구 방법}

신체 계측 항목인 체중, 키, 허리둘레는 검진조사를 통해 직접 측 정하였고 체질량지수는 체중 $(\mathrm{kg}) /$ 키 $(\mathrm{m})^{2}$ 으로 계산된 수치를 이용 하였다. 혈압은 총 3회 측정한 후 최종 보정값으로 제시된 평균 수 축기 • 이완기 혈압을 이용하였다. 혈액 검사는 공복 상태에서 정맥
채혈을 시행하여 분리된 혈청으로 공복 혈당, AST, ALT, GGT, alkaline phosphatase (ALP), 총 콜레스테롤, 고밀도지단백(high density lipoprotein, $\mathrm{HDL}$ ) 콜레스테롤, 저밀도지단백(low density lipoprotein, LDL) 콜레스테롤, 중성지방을 측정하였다. 측정 시약 및 방법은 공복 혈당의 경우 Pureauto S GLU를 이용하 여 효소법으로 측정하였고, AST와 ALT는 Pureauto S AST, Pureauto S ALT를 이용하여 UV 법으로, GGT는 Pureauto S GGT, ALP는 Pureauto S ALP를 이용한 효소법으로 측정하였다. 총콜레 스테롤은 Pureauto SCHO-N, HDL콜레스테롤은 Cholestest N $\mathrm{HDL}, \mathrm{LDL}$ 콜레스테롤은 Cholestest $\mathrm{LDL}$, 중성지방은 Pureauto S TG-N (Daiichi Pure Chemicals Corporation, Tokyo, Japan)을 사용하여 효소법으로 측정하였다. 측정 장비는 Hitachi 7600 (Hitachi high-technologies Co., Tokyo, Japan) 자동화학 분석기 를 사용하였다.

음주 관련 빈도는 '전혀 마시지 않음'에 해당하는 경우 none, '월 1회 미만'에서 ‘월 2 4회'의 경우 mild, '주 2 3회'와 ‘주 4회'에 해당하는 경우 moderate로 분류하였다. 음주량은 '비해당' 에 해당 하는 경우 none, '1회 3 4잔' 이하의 경우 mild, '1회 10잔' 이하 에 해당하는 경우 moderate로 분류하였다. 흡연의 경우 비흡연과 과거 흡연자, 현재 흡연자로 구분하였다.

FRS는 Framingham heart study [15]를 통해 제시된 항목, 즉 연령, LDL 콜레스테롤 또는 총 콜레스테롤, $\mathrm{HDL}$ 콜레스테롤, 수축 기 혈압, 이완기 혈압, 당뇨병 유무, 흡연여부에 따라 $\mathrm{LDL}$ 콜레스테 롤 점수 또는 총 콜레스테롤 점수 기준으로 점수화하여 이에 대한 총합을 바탕으로 관상동맥질환의 10 년 위험도에 대한 예측치를 제 공한다. 남성에서 연령의 경우 30 세 이상에서 5 년 구간별로 나누어 -1 7점, 총 콜레스테롤은 5개 구간으로 나누어 -3 3점, $\mathrm{HDL}$ 콜 레스테롤 콜레스테롤은 5 개 구간으로 나누어 -2 2점, 수축기 혈 압과 이완기 혈압은 각각 5 개 구간으로 나누어 0 3점, 당뇨병 유 무에 따라 0 점 또는 2점, 흡연여부에 따라 비흡연 또는 과거흡연자 의 경우 0 점, 현재 흡연자의 경우 2점으로 점수가 구간별로 부여되 어 있다. 관상동맥질환의 10 년 위험도에 대한 예측치는 남성의 경 우 FRS - 1 미만에서 14 이상 점수별로 최저 $2 \%$ 에서 최대 $53 \%$ 이상 까지 제시되어 있다. 본 연구에서 FRS는 Framingham heart study 에서 남녀 성별에 따라 다르게 제시한 기준을 각각 사용하였으며, 총 콜레스테롤 점수로 환산한 총합과 10 년 위험도를 적용하였다.

\section{3. 통계분석}

GGT의 경우 성별에 따라 정상치가 다르게 적용되므로 남자의 경우 정상 범위는 10 71 U/L, 여자의 경우 6 42 U/L의 범위에서 성별에 따라 각각 GGT 수준에 따라 네 개의 그룹으로 나누어 분석 
하였다. 남성에서 GGT(IU/L) 수준에 따라 사분위수(quartile) 네 군으로 나누었을 때 GGT기준은 10 20 IU/L, 21 27 IU/L, 28 $38 \mathrm{IU} / \mathrm{L}, 39 \sim 71 \mathrm{IU} / \mathrm{L}$ 이었으며, 여성의 경우 6 12 IU/L, 13 16 $\mathrm{IU} / \mathrm{L}, 17 \sim 22 \mathrm{IU} / \mathrm{L}, 23 \sim 42 \mathrm{IU} / \mathrm{L}$ 이었다. 관상동맥질환 위험인자 와 GGT의 상관관계는 Pearson's 상관계수, 연령에 따른 분포의 차 이는 Chi-square test, 성별에 따른 GGT 수준별 심혈관 위험 요인 과의 관련성은 분산분석(analysis of variance, $\mathrm{ANOVA}$ )과 Scheffe 사후검정으로 분석하고 평균ㅍ표준편차로 표시하였으며, 경향성 검정은 선형 대 선형 결합을 이용하였다. 자료에 대한 통계 분석은 SPSS 17.0 (SPSS Inc., Chicago, IL, USA)을 사용하였으며, $p$ 값은 0.05 미만의 경우 유의한 것으로 판정하였다.

\section{결 과}

\section{1. 대상자의 일반적 특성}

남성의 평균 연령은 52.4세, 여성은 51.1세이었으며, 일반적인 신체 계측치 및 혈압은 남성에서 유의하게 크게 나타났다. 공복 혈 당은 $99.8 \pm 22.5 \mathrm{mg} / \mathrm{dL}$, AST $20.9 \pm 4.4 \mathrm{IU} / \mathrm{L}$, ALT $19.9 \pm 6.9$ IU/L, GGT 30.7 \pm 14.1 IU/L, ALP 231.4 \pm 57.9 IU/L, 중성지방 수 치가 $144.2 \pm 101.7 \mathrm{mg} / \mathrm{dL}$ 로 남성에서 유의하게 높았다. 총 콜레 스테롤은 $194.0 \pm 37.7 \mathrm{mg} / \mathrm{dL}$, 고밀도콜레스테롤은 $50.6 \pm 10.9$ $\mathrm{mg} / \mathrm{dL}$ 로 여성에서 더 높게 나타났으며, 통계적으로 유의한 차이가 있었다. 저밀도 콜레스테롤은 성별에 따른 차이를 보이지 않았다. FRS는 남성에서 $5.0 \pm 3.4$, 여성에서 $2.3 \pm 7.9,10$ 년 관상동맥질환 위험도는 남성에서 $10.9 \pm 8.5 \%$, 여성에서 $7.0 \pm 5.2 \%$ 로 나타나 모 두 남성이 유의하게 높았다(Table 1).

Table 1. The general characteristics of the subjects

\begin{tabular}{|c|c|c|c|c|}
\hline variables & Total $(\mathrm{N}=3619)$ & Men $(\mathrm{N}=1354)$ & Women $(\mathrm{N}=2265)$ & $p$-value* \\
\hline Age (year) & $51.6 \pm 12.7$ & $52.4 \pm 12.9$ & $51.1 \pm 12.6$ & 0.002 \\
\hline Height $(\mathrm{cm})$ & $161.4 \pm 8.6$ & $169.4 \pm 6.2$ & $156.7 \pm 5.8$ & $<0.001$ \\
\hline Weight (kg) & $61.7 \pm 10.5$ & $68.4 \pm 10.0$ & $57.7 \pm 8.5$ & $<0.001$ \\
\hline BMI $\left(\mathrm{kg} / \mathrm{m}^{2}\right)$ & $23.6 \pm 3.1$ & $23.8 \pm 2.9$ & $23.5 \pm 3.3$ & 0.010 \\
\hline$W C(\mathrm{~cm})$ & $81.0 \pm 9.4$ & $84.3 \pm 8.4$ & $79.0 \pm 9.4$ & $<0.001$ \\
\hline $\mathrm{SBP}(\mathrm{mmHg})$ & $118.3 \pm 16.9$ & $120.2 \pm 15.4$ & $117.2 \pm 17.6$ & $<0.001$ \\
\hline $\mathrm{DBP}(\mathrm{mmHg})$ & $75.9 \pm 9.8$ & $78.1 \pm 9.9$ & $74.5 \pm 9.5$ & $<0.001$ \\
\hline Fasting glucose (mg/dL) & $96.8 \pm 20.2$ & $99.8 \pm 22.5$ & $95.0 \pm 18.5$ & $<0.001$ \\
\hline AST (IU/L) & $19.8 \pm 4.4$ & $20.9 \pm 4.4$ & $19.1 \pm 4.3$ & $<0.001$ \\
\hline ALT (IU/L) & $17.2 \pm 6.5$ & $19.9 \pm 6.9$ & $15.6 \pm 5.7$ & $<0.001$ \\
\hline GGT (IU/L) & $22.8 \pm 12.0$ & $30.7 \pm 14.1$ & $18.0 \pm 7.0$ & $<0.001$ \\
\hline ALP (IU/L) & $223.1 \pm 75.8$ & $231.4 \pm 57.9$ & $218.1 \pm 84.4$ & $<0.001$ \\
\hline Total cholesterol (mg/dL) & $192.4 \pm 36.2$ & $189.7 \pm 33.2$ & $194.0 \pm 37.7$ & $<0.001$ \\
\hline HDL cholesterol (mg/dL) & $48.7 \pm 10.9$ & $45.6 \pm 10.2$ & $50.6 \pm 10.9$ & $<0.001$ \\
\hline $\mathrm{LDL}$ cholesterol $(\mathrm{mg} / \mathrm{dL})^{\dagger}$ & $117.9 \pm 31.3$ & $117.9 \pm 29.1$ & $117.8 \pm 32.9$ & 0.974 \\
\hline Triglyceride $(\mathrm{mg} / \mathrm{dL})$ & $126.6 \pm 90.4$ & $144.2 \pm 101.7$ & $116.1 \pm 81.2$ & $<0.001$ \\
\hline \multicolumn{5}{|l|}{ Alcohol consumption (frequency) } \\
\hline None & $1051(29.0)$ & $223(16.5)$ & $828(36.5)$ & $<0.001$ \\
\hline Mild & $1938(53.6)$ & $675(49.8)$ & $1263(55.8)$ & \\
\hline Moderate & $630(17.4)$ & $456(33.7)$ & $174(7.7)$ & \\
\hline \multicolumn{5}{|l|}{ Alcohol consumption (amount) } \\
\hline None & $1037(28.7)$ & $217(16.0)$ & $820(36.2)$ & $<0.001$ \\
\hline Mild & $1785(49.3)$ & $544(40.2)$ & $1241(54.8)$ & \\
\hline Moderate & $797(22.0)$ & $593(43.8)$ & $204(9.0)$ & \\
\hline \multicolumn{5}{|l|}{ Smoking status } \\
\hline None or ex smoker & $2988(82.6)$ & $827(61.1)$ & $2161(95.4)$ & $<0.001$ \\
\hline Current smoker & $631(17.4)$ & $527(38.9)$ & $104(4.6)$ & \\
\hline Framingham Risk scores (points) & $3.3 \pm 6.7$ & $5.0 \pm 3.4$ & $2.3 \pm 7.9$ & $<0.001$ \\
\hline 10-year CHD risk (\%) & $8.8 \pm 7.2$ & $10.9 \pm 8.5$ & $7.0 \pm 5.2$ & $<0.001$ \\
\hline
\end{tabular}

Data are presented as mean \pm standard deviation or number (\%).

${ }^{*}$ T-test and Chi-square test were assessed for continuous and categorical variables, respectively.

† Only 1184 subjects ( $n=506$ in men, $n=678$ in women) among total subjects had data of LDL cholesterol (direct method).

Abbreviation: BMI, body mass index; WC, Waist circumference; SBP, systolic blood pressure; DBP, diastolic blood pressure; AST, aspartate aminotransferase; ALT, alanine aminotransferase; GGT, $\gamma$-glutamyltransferase; ALP, alkaline phosphatase; HDL, high-density lipoprotein cholesterol; LDL, low-density lipoprotein cholesterol; CHD, coronary heart disease. 


\section{2. 관상동맥질환 위험인자와 GGT의 상관관계}

각각의 신체지수 및 혈액검사 항목과 GGT 수치 간의 이변량상 관분석 결과 뚜렷한 양의 상관관계를 보이는 항목은 ALT 였으며(남 성에서 $r=0.354$, 여성에서 $r=0.446$ ), 남녀 모두 통계적으로 유의하 였다 $(p<0.001)$. 연령의 경우 남성에서 상관계수는 -0.053 으로 나 타나 음의 상관관계이나 통계적으로 유의하지 않았고, 여성의 경우 0.236 으로 유의한 약한 양의 상관관계를 보여 남녀간의 차이가 있 었다. 남성에서 연령, 키, 고밀도 콜레스테롤, 저밀도 콜레스테롤을 제외한 나머지 항목은 통계적으로 유의하였으나 대부분 상관계수 가 -0.1 0.3 사이에 존재하여 약한 상관성을 보였다(Table 2).

\section{3. 남성에서 GGT 수준에 따른 요인별 특성}

남성에서 GGT (IU/L) 수준에 따라 사분위수(quartile) 네 군으 로 나누었을 때 GGT기준은 1 사분위는 10 20으로 358 명, 2 사분
Table 2. Correlation coefficients between risk factors of coronary heart disease and GGT

\begin{tabular}{|c|c|c|c|c|}
\hline \multirow{2}{*}{ variables } & \multicolumn{2}{|c|}{ Men } & \multicolumn{2}{|c|}{ Women } \\
\hline & r & $p$-value* & r & $p$-value* \\
\hline Age (year) & -0.053 & 0.053 & 0.236 & $<0.001$ \\
\hline Height $(\mathrm{cm})$ & -0.008 & 0.772 & -0.140 & $<0.001$ \\
\hline Weight (kg) & 0.193 & $<0.001$ & 0.191 & $<0.001$ \\
\hline BMI $\left(\mathrm{kg} / \mathrm{m}^{2}\right)$ & 0.236 & $<0.001$ & 0.275 & $<0.001$ \\
\hline$W C(\mathrm{~cm})$ & 0.253 & $<0.001$ & 0.301 & $<0.001$ \\
\hline $\mathrm{SBP}(\mathrm{mmHg})$ & 0.150 & $<0.001$ & 0.231 & $<0.001$ \\
\hline $\mathrm{DBP}(\mathrm{mmHg})$ & 0.193 & $<0.001$ & 0.191 & $<0.001$ \\
\hline Fasting glucose (mg/dL) & 0.120 & $<0.001$ & 0.236 & $<0.001$ \\
\hline AST (IU/L) & 0.227 & $<0.001$ & 0.319 & $<0.001$ \\
\hline ALT (IU/L) & 0.354 & $<0.001$ & 0.446 & $<0.001$ \\
\hline ALP (IU/L) & 0.047 & $<0.001$ & 0.165 & $<0.001$ \\
\hline Total cholesterol (mg/dL) & 0.158 & $<0.001$ & 0.194 & $<0.001$ \\
\hline HDL cholesterol (mg/dL) & 0.039 & 0.150 & -0.086 & $<0.001$ \\
\hline LDL cholesterol (mg/dL) & 0.040 & 0.367 & 0.157 & $<0.001$ \\
\hline Triglyceride (mg/dL) & 0.252 & $<0.001$ & 0.290 & $<0.001$ \\
\hline
\end{tabular}

*Pearson's correlation test.

See Table 1.

Table 3. Risk factors of coronary heart disease according to quartiles of serum gamma-glutamyltransferase level in men

\begin{tabular}{|c|c|c|c|c|c|c|}
\hline \multirow{2}{*}{ variables } & $\begin{array}{c}1^{\text {st }} \text { Quartile } \\
(\mathrm{N}=358)\end{array}$ & $\begin{array}{c}2^{\text {nd }} \text { Quartile } \\
(\mathrm{N}=342)\end{array}$ & $\begin{array}{c}3^{\text {rd }} \text { Quartile } \\
(\mathrm{N}=318)\end{array}$ & $\begin{array}{c}4^{\text {th }} \text { Quartile } \\
(N=336)\end{array}$ & \multirow[t]{2}{*}{$p$-value* } & \multirow{2}{*}{$\begin{array}{l}p \text { for } \\
\text { trend }\end{array}$} \\
\hline & GGT $10 \sim 20(\mathrm{IU} / \mathrm{L})$ & GGT $21 \sim 27(\mathrm{IU} / \mathrm{L})$ & GGT 28 38 (IU/L) & GGT 39 71 (IU/L) & & \\
\hline Age (year) & $53.0 \pm 13.9^{\dagger, \dagger}$ & $53.9 \pm 13.1^{\ddagger}$ & $51.1 \pm 12.3^{\dagger}$ & $51.4 \pm 12.2^{\dagger, \neq}$ & 0.015 & 0.014 \\
\hline Height $(\mathrm{cm})$ & $169.4 \pm 6.2^{\dagger}$ & $169.1 \pm 6.2$ & $169.8 \pm 6.5$ & $169.4 \pm 5.9$ & 0.583 & 0.744 \\
\hline Weight (kg) & $65.1 \pm 8.9^{\dagger}$ & $67.6 \pm 8.9^{\ddagger}$ & $70.5 \pm 11.5^{\S}$ & $70.8 \pm 9.7^{\S}$ & $<0.001$ & $<0.001$ \\
\hline $\mathrm{BMI}\left(\mathrm{kg} / \mathrm{m}^{2}\right)$ & $22.6 \pm 2.5^{\dagger}$ & $23.6 \pm 2.7^{\ddagger}$ & $24.3 \pm 3.0^{\S}$ & $24.6 \pm 2.8^{\S}$ & $<0.001$ & $<0.001$ \\
\hline WC $(\mathrm{cm})$ & $80.8 \pm 7.9^{\dagger}$ & $83.8 \pm 7.6^{\ddagger}$ & $85.8 \pm 9.2^{\S}$ & $87.0 \pm 7.4^{8}$ & $<0.001$ & $<0.001$ \\
\hline $\mathrm{SBP}(\mathrm{mmHg})$ & $116.0 \pm 15.8^{\dagger}$ & $120.6 \pm 15.4^{\ddagger}$ & $121.5 \pm 15.3^{\ddagger}$ & $122.8 \pm 14.1^{\ddagger}$ & $<0.001$ & $<0.001$ \\
\hline DBP $(\mathrm{mmHg})$ & $74.6 \pm 9.4^{\dagger}$ & $78.1 \pm 9.9^{\ddagger}$ & $79.3 \pm 10.0^{\ddagger, \S}$ & $80.5 \pm 9.4^{\S}$ & $<0.001$ & $<0.001$ \\
\hline Fasting glucose (mg/dL) & $97.0 \pm 20.2^{\dagger}$ & $98.3 \pm 20.2^{\dagger}$ & $100.4 \pm 20.5^{\dagger, \ddagger}$ & $103.6 \pm 27.7^{\ddagger}$ & 0.001 & $<0.001$ \\
\hline AST $(I U / L)$ & $19.7 \pm 4.3^{\dagger}$ & $20.5 \pm 4.2^{\dagger, \ddagger}$ & $21.0 \pm 4.4^{\mp}$ & $22.5 \pm 4.4^{\S}$ & $<0.001$ & $<0.001$ \\
\hline $\operatorname{ALT}(\mathrm{IU} / \mathrm{L})$ & $16.8 \pm 5.8^{\dagger}$ & $19.0 \pm 6.1^{\ddagger}$ & $20.6 \pm 6.8^{\S}$ & $23.6 \pm 7.1^{\|}$ & $<0.001$ & $<0.001$ \\
\hline ALP (IU/L) & $229.3 \pm 56.9^{\dagger, \uparrow}$ & $231.4 \pm 56.3^{\dagger, \uparrow}$ & $226.1 \pm 56.2^{\dagger}$ & $238.8 \pm 61.3^{\ddagger}$ & 0.034 & 0.091 \\
\hline T-cholesterol(mg/dL) & $180.3 \pm 31.1^{\dagger}$ & $190.2 \pm 33.5^{\ddagger}$ & $193.4 \pm 31.5^{\ddagger}$ & $195.5 \pm 34.7^{\ddagger}$ & $<0.001$ & $<0.001$ \\
\hline HDL cholesterol (mg/dL) & $46.2 \pm 9.7$ & $45.1 \pm 10.6$ & $44.8 \pm 9.8$ & $46.4 \pm 10.7$ & 0.116 & 0.878 \\
\hline LDL cholesterol (mg/dL) & $110.3 \pm 28.2^{\dagger}$ & $123.1 \pm 27.9^{\ddagger}$ & $121.9 \pm 27.8^{\ddagger}$ & $116.7 \pm 31.0^{\dagger, \ddagger}$ & 0.002 & 0.115 \\
\hline Triglyceride $(\mathrm{mg} / \mathrm{dL})$ & $107.9 \pm 74.1^{\dagger}$ & $136.5 \pm 85.7^{\ddagger}$ & $155.3 \pm 108.2^{\ddagger}$ & $180.3 \pm 120.5^{\S}$ & $<0.001$ & $<0.001$ \\
\hline \multicolumn{7}{|l|}{ Alcohol consumption (freq) } \\
\hline None & $98(27.4)$ & $59(17.3)$ & $35(11.0)$ & $31(9.2)$ & $<0.001$ & $<0.001$ \\
\hline Mild & $195(54.4)$ & $190(55.5)$ & $155(48.7)$ & $135(40.2)$ & & \\
\hline Moderate & $65(18.2)$ & $93(27.2)$ & $128(40.3)$ & $170(50.6)$ & & \\
\hline \multicolumn{7}{|l|}{ Alcohol consumption(amount) } \\
\hline None & $97(27.1)$ & $59(17.3)$ & $33(10.4)$ & $28(8.3)$ & $<0.001$ & $<0.001$ \\
\hline Mild & $159(44.4)$ & $166(48.5)$ & $126(39.6)$ & $93(27.7)$ & & \\
\hline Moderate & $102(28.5)$ & $117(34.2)$ & $159(50.0)$ & $215(64.0)$ & & \\
\hline \multicolumn{7}{|l|}{ Smoking status } \\
\hline None or ex smoker & $248(69.3)$ & $213(62.3)$ & $181(56.9)$ & $185(55.1)$ & $<0.001$ & $<0.001$ \\
\hline Current smoker & $110(30.7)$ & $129(37.7)$ & $137(43.1)$ & $151(44.9)$ & & \\
\hline Framingham Risk scores (points) & $4.4 \pm 3.6^{\dagger}$ & $5.4 \pm 3.5^{\ddagger}$ & $5.2 \pm 3.1^{\ddagger}$ & $5.2 \pm 3.0^{\ddagger}$ & $<0.001$ & 0.006 \\
\hline 10-year CHD risk (\%) & $9.9 \pm 8.0^{\dagger}$ & $12.1 \pm 9.5^{\ddagger}$ & $11.0 \pm 7.9^{\dagger, \ddagger}$ & $10.7 \pm 8.3^{\dagger, \ddagger}$ & 0.010 & 0.563 \\
\hline
\end{tabular}

*ANOVA and Chi-square test were assessed for continuous and categorical variables, respectively.

$\dagger, \neq, \S, \|$ Post-hoc analysis by Scheffe.

See Table 1. 
위는 21 27으로 342 명, 3 사분위는 28 38으로 318 명, 4 사분위 는 39 71으로 336명이었다.

남성의 경우 키와 고밀도콜레스테롤을 제외한 모든 항목에서 GGT수치 각 분위수 간 유의한 차이를 보였다. 연령과 저밀도콜레 스테롤은 GGT 2분위수에서 수치가 가장 높았으나 이를 제외한 나 머지 항목은 GGT 4분위수로 갈수록 수치가 높게 나타났다. AST와 ALT는 GGT 4분위수로 갈수록 수치가 높아졌으며, 사후분석 결과 GGT 1분위수와 4분위수 간의 차이가 크고 통계적으로 유의하였 고 그 차이는 ALT에서 더 뚜렷하게 나타났다. 총 콜레스테롤과 중 성지방 또한 GGT 4분위수로 갈수록 수치가 높아졌으며, 사후분석 결과 1 분위수와 $2,3,4$ 분위수간의 차이가 통계적으로 유의하였다. 경향분석 결과 체중, 체질량지수, 허리둘레, 수축기혈압, 이완기혈 압, 공복 혈당, AST, ALT, 총 콜레스테롤, 중성지방은 GGT 분위수 가 높아질수록 수치가 높아지는 경향을 보였다( $p$ for trend <0.001). FRS는 1분위수 4.4점, 2분위수5.4점, 3분위수 5.2점, 4 분위수 5.2점으로 나타났고, 10 년 심혈관 질환 위험도는 1 분위수 $9.9 \%, 2$ 분위수 $12.1 \%, 3$ 분위수 $11.0 \%, 4$ 분위수 $10.7 \%$ 로 나타나 GGT 2분위수에서 유의하게 높았다(Table 3, Fig. 1A).
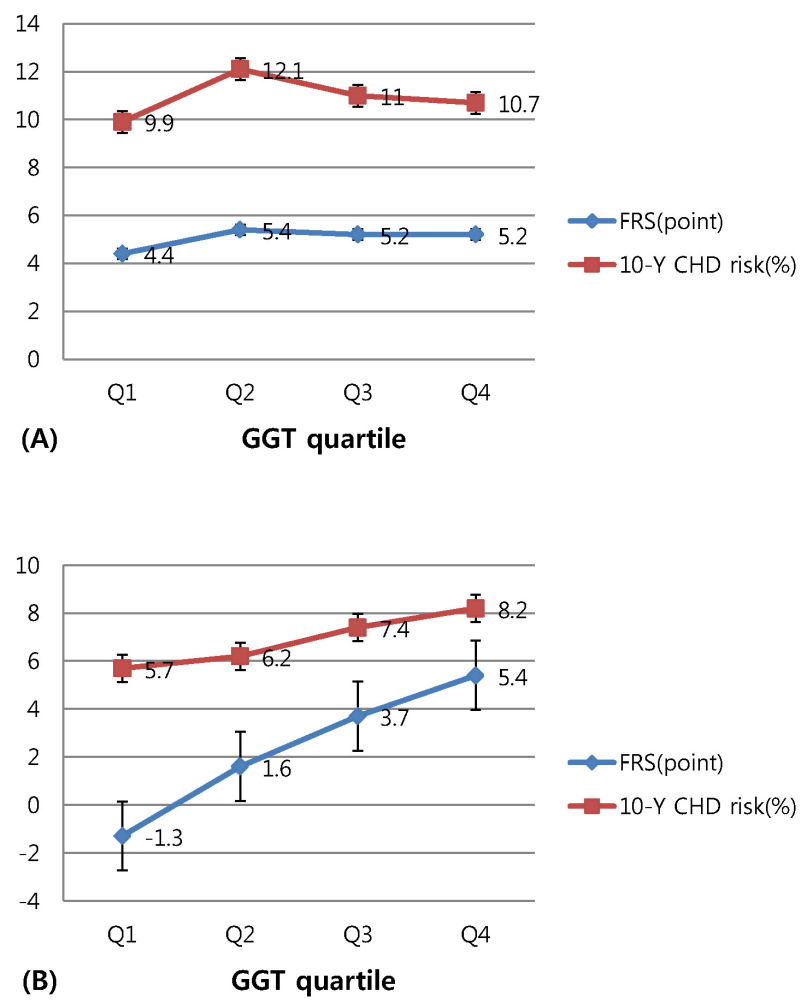

Fig. 1. Change of FRS and 10-year CHD risk according to GGT quartile. (A) The FRS and 10-year CHD risk was the highest in $2^{\text {nd }}$ quartile (Q2) in men, (B) while being the highest in $4^{\text {th }}$ quartile (Q4) in women. Abbreviation: Q1, $1^{\text {st }}$ quartile; Q2, $2^{\text {nd }}$ quartile; Q3, $3^{\text {th }}$ quartile; Q4, $4^{\text {th }}$ quartile.

\section{4. 여성에서 GGT 수준에 따른 요인별 특성}

여성에서 GGT (IU/L) 수준에 따라 사분위수(quartile) 네 군으 로 나누었을 때 GGT기준은 1 사분위는 6 12로 518명, 13 16으 로 662명, 17 22로 574명, 23 42로 511명이었다.

여성의 경우 키와 고밀도콜레스테롤은 1 분위수에서 가장 높은 수치를 보였고 통계적으로 유의한 차이가 나타났으며, 이를 제외한 나머지 항목은 GGT 4분위수로 갈수록 수치가 높게 나타났다 $p$ for trend<0.001). 사후분석 결과 연령, 체질량지수, 허리둘레, 수축 기혈압, AST, ALT, 중성지방에서 네 군간 평균치는 모두 유의한 차 이가 있었으며, 체중, 공복 혈당, ALP 에서 1,2 분위수와 3 분위수, 4 분위수간 유의한 차이가 있었다. FRS는 1분위수 -1.3 점, 2 분위수 1.6점, 3분위수 3.7점, 4분위수 5.4점으로 나타났고, 10년 심혈관 질환 위험도는 1 분위수 $5.7 \%, 2$ 분위수 $6.2 \%, 3$ 분위수 $7.4 \%, 4$ 분위 수 $8.2 \%$ 로 나타나 모두 GGT 4분위수에서 유의하게 높은 선형관계 가 있었다 ( $p$ for trend <0.001) (Table 4, Fig. 1B).

\section{5. 연령에 따른 GGT 수치 분포}

연령군에 따라 GGT 사분위수의 분포를 살펴본 결과 30 대의 경
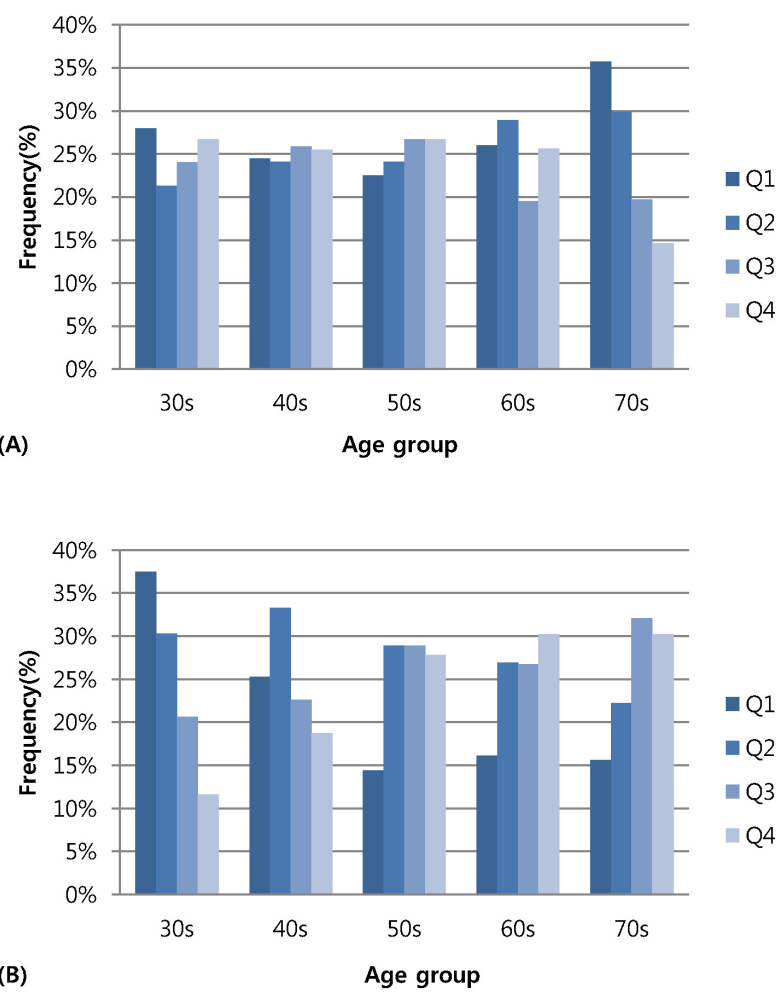

Fig. 2. Distribution of GGT quartile according to age group. In the 70's, (A) there was the highest Q1 and Q2 in men and (B) there was the highest Q3 and Q4 in women. Abbreviation: Q1, $1^{\text {st }}$ quartile; Q2, $2^{\text {nd }}$ quartile; Q3, $3^{\text {th }}$ quartile; Q4, $4^{\text {th }}$ quartile. 
Table 4. Risk factors of coronary heart disease according to quartiles of serum gamma-glutamyltransferase level in women

\begin{tabular}{|c|c|c|c|c|c|c|}
\hline \multirow[t]{2}{*}{ variables } & $\begin{array}{c}1^{\text {st }} \text { Quartile } \\
(\mathrm{N}=518)\end{array}$ & $\begin{array}{c}2^{\text {nd }} \text { Quartile } \\
(\mathrm{N}=662)\end{array}$ & $\begin{array}{c}3^{\text {rd }} \text { Quartile } \\
(\mathrm{N}=574)\end{array}$ & $\begin{array}{c}4^{\text {th }} \text { Quartile } \\
(\mathrm{N}=511)\end{array}$ & \multirow[t]{2}{*}{$p$-value* } & \multirow{2}{*}{$\begin{array}{l}p \text { for } \\
\text { trend* }\end{array}$} \\
\hline & GGT6 $12(\mathrm{IU} / \mathrm{L})$ & GGT13 16 (IU/L) & GGT17 22(IU/L) & GGT23 42 (IU/L) & & \\
\hline Age (year) & $46.6 \pm 12.7^{\dagger}$ & $49.9 \pm 12.1^{\ddagger}$ & $52.9 \pm 12.4^{\S}$ & $55.1 \pm 11.8^{\| \prime}$ & $<0.001$ & $<0.001$ \\
\hline Height $(\mathrm{cm})$ & $157.9 \pm 6.0^{\S}$ & $157.0 \pm 5.5^{\ddagger}$ & $156.3 \pm 5.7^{\dagger, \uparrow}$ & $155.5 \pm 5.6^{\dagger}$ & $<0.001$ & $<0.001$ \\
\hline Weight (kg) & $55.6 \pm 7.4^{\dagger}$ & $56.8 \pm 8.4^{\dagger}$ & $58.7 \pm 8.2^{\ddagger}$ & $59.8 \pm 9.3^{\ddagger}$ & $<0.001$ & $<0.001$ \\
\hline $\mathrm{BMI}\left(\mathrm{kg} / \mathrm{m}^{2}\right)$ & $22.3 \pm 2.6^{\dagger}$ & $23.0 \pm 3.2^{\ddagger}$ & $24.0 \pm 3.2^{\S}$ & $24.7 \pm 3.6^{\prime \prime}$ & $<0.001$ & $<0.001$ \\
\hline$W C(\mathrm{~cm})$ & $75.2 \pm 7.9^{\dagger}$ & $77.5 \pm 8.9^{\ddagger}$ & $80.5 \pm 9.0^{\S}$ & $83.0 \pm 9.9^{\| \prime}$ & $<0.001$ & $<0.001$ \\
\hline $\mathrm{SBP}(\mathrm{mmHg})$ & $111.2 \pm 15.4^{\dagger}$ & $115.8 \pm 18.0^{\ddagger}$ & $119.4 \pm 16.8^{\S}$ & $122.8 \pm 18.0^{\|}$ & $<0.001$ & $<0.001$ \\
\hline $\mathrm{DBP}(\mathrm{mmHg})$ & $71.5 \pm 9.1^{\dagger}$ & $74.1 \pm 9.5^{\ddagger}$ & $75.4 \pm 9.4^{\ddagger}$ & $77.1 \pm 9.1^{\S}$ & $<0.001$ & $<0.001$ \\
\hline Fasting glucose (mg/dL) & $90.1 \pm 13.2^{\dagger}$ & $91.8 \pm 12.9^{\dagger}$ & $97.1 \pm 18.1^{\ddagger}$ & $101.8 \pm 26.0^{\S}$ & $<0.001$ & $<0.001$ \\
\hline AST $(I U / L)$ & $17.4 \pm 4.0^{\dagger}$ & $18.5 \pm 3.9^{\mp}$ & $19.7 \pm 4.2^{\S}$ & $21.1 \pm 4.5^{\|}$ & $<0.001$ & $<0.001$ \\
\hline ALT (IU/L) & $12.3 \pm 4.0^{\dagger}$ & $14.6 \pm 5.0^{\ddagger}$ & $16.6 \pm 5.2^{\S}$ & $19.2 \pm 6.1^{\| 1}$ & $<0.001$ & $<0.001$ \\
\hline ALP (IU/L) & $202.4 \pm 120.9^{\dagger}$ & $209.3 \pm 67.3^{\dagger}$ & $223.6 \pm 71.1^{\ddagger}$ & $239.1 \pm 66.5^{\S}$ & $<0.001$ & $<0.001$ \\
\hline T-cholesterol $(\mathrm{mg} / \mathrm{dL})$ & $182.4 \pm 34.0^{\dagger}$ & $192.5 \pm 36.0^{\ddagger}$ & $198.3 \pm 37.7$ & $202.8 \pm 40.4^{\S}$ & $<0.001$ & $<0.001$ \\
\hline HDL cholesterol (mg/dL) & $52.0 \pm 10.9^{\ddagger}$ & $51.4 \pm 10.5^{\ddagger}$ & $49.6 \pm 11.0^{\dagger}$ & $49.1 \pm 11.0^{\dagger}$ & $<0.001$ & $<0.001$ \\
\hline LDL cholesterol (mg/dL) & $107.6 \pm 31.8^{\dagger}$ & $119.7 \pm 32.2^{\ddagger}$ & $120.2 \pm 32.4^{\ddagger}$ & $123.7 \pm 33.4^{\ddagger}$ & $<0.001$ & $<0.001$ \\
\hline Triglyceride $(\mathrm{mg} / \mathrm{dL})$ & $88.1 \pm 48.0^{\dagger}$ & $102.4 \pm 55.0^{\ddagger}$ & $128.2 \pm 78.7^{\S}$ & $148.7 \pm 117.4^{\|}$ & $<0.001$ & $<0.001$ \\
\hline Alcohol consumption (freq) & & & & & $<0.001$ & $<0.001$ \\
\hline None & $196(37.9)$ & $221(33.4)$ & $204(35.5)$ & $207(40.5)$ & 0.008 & 0.864 \\
\hline Mild & $298(57.5)$ & $389(58.8)$ & $314(54.7)$ & $262(51.3)$ & & \\
\hline Moderate & $24(4.6)$ & $52(7.8)$ & $56(9.8)$ & $42(8.2)$ & & \\
\hline \multicolumn{7}{|l|}{ Alcohol consumption(amount) } \\
\hline None & $196(37.9)$ & $216(32.6)$ & $203(35.4)$ & $205(40.1)$ & 0.012 & 0.795 \\
\hline Mild & $284(54.8)$ & $392(59.2)$ & $317(55.2)$ & $248(48.5)$ & & \\
\hline Moderate & $38(7.3)$ & $54(8.2)$ & $54(9.4)$ & $58(11.4)$ & & \\
\hline \multicolumn{7}{|l|}{ Smoking status } \\
\hline None or ex smoker & $500(96.5)$ & $635(95.9)$ & $548(95.5)$ & $478(93.5)$ & 0.115 & 0.022 \\
\hline Current smoker & $18(3.5)$ & $27(4.1)$ & $26(4.5)$ & $33(6.5)$ & & \\
\hline Framingham Risk scores (points) & $-1.3 \pm 8.2^{\dagger}$ & $1.6 \pm 7.7^{\ddagger}$ & $3.7 \pm 7.4^{\S}$ & $5.4 \pm 6.9^{\|}$ & $<0.001$ & $<0.001$ \\
\hline 10-year CHD risk (\%) & $5.7 \pm 4.6^{\dagger}$ & $6.2 \pm 4.6^{\dagger}$ & $7.4 \pm 5.3^{\ddagger}$ & $8.2 \pm 5.8^{\ddagger}$ & $<0.001$ & $<0.001$ \\
\hline
\end{tabular}

*ANOVA and Chi-square test were assessed for continuous and categorical variables, respectively.

$t, \uparrow, \S, \|$ Post-hoc analysis by Scheffe.

See Table 1.

우 남녀 모두 GGT 수치 1분위수에 해당하는 비율이 가장 높았다. 남성은 40대와 50대로 연령이 증가할수록 3분위수와 4 분위수의 비율이 증가하다가 60 대에서 2 분위수의 비율이, 70 대에서 1 분위 수의 비율이 가장 높게 나타났다. 여성의 경우 연령이 증가할수록 3 분위수와 4 분위수에 해당하는 비율이 점점 높게 나타났다(Fig. 2).

\section{고 찰}

본 연구에서는 간기능 검사 이상자와 고도의 음주자를 모두 제 외한 상태에서 정상 범위에 속하는 GGT 수치와 관상동맥질환 위 험 요인과의 관련성을 살펴본 결과 혈중 GGT 수치가 증가함에 따 라 성별에 따라 서로 다른 양상을 보였다.

남녀 모두 체중, 체질량지수, 허리둘레, 수축기 혈압, 이완기 혈 압, 혈당, AST, ALT, ALP, 총 콜레스테롤, 중성지방에서 GGT 4분 위수로 갈수록 수치가 높게 나타났다. 이는 고혈압, 당뇨, 대사증후
군 관련 연구에서 제시한 GGT 수치와의 관련성과 서로 일치한다 [5-9]. 특히 고밀도콜레스테롤을 제외한 나머지 대사증후군에 포 함되는 항목들이 GGT 수준과 유의한 양의 용량 반응이 있음을 입 증한 결과와도 일치하며[16], 고밀도콜레스테롤의 경우 남성에서 는 통계적으로 유의하지 않고 선형관계가 나타나지 않았으나 여성 의 경우는 GGT 수준이 높아질수록 수치가 낮게 나타났는데 이는 지단백 관련 선행 연구에서 GGT 수치와의 관련성이 없거나 낮다 고 제시한 결과와도 부분적으로 유사하다[17].

그러나 연령과 GGT 수치는 남성에서 통계적으로 비유의한 음 의 상관관계가 나타나고, 여성에서는 약한 양의 상관관계가 나타나 GGT가 연령(r=0.296)에서 유의성이 입증되었던 선행 연구[18]와 다른 양상을 보였는데 본 연구에서 GGT 수치에 따른 대상자의 연 령 분포에 의한 차이가 관상동맥 질환 관련 지표에 영향을 미친 것 으로 여겨진다.

FRS와 10 년 관상동맥 질환 위험도는 남성이 여성보다 더 유의하 
게 높게 나타났고 이는 기존 연구들과도 일치한다[13,19,20]. 그러 나 선행 연구에서 남녀 모두 FRS와 10년 심혈관 질환 위험도는 GGT 수준이 높아질수록 증가하였으나[13,19], 본 연구에서는 여 성의 경우 GGT 수준이 높아질수록 FRS와 10년 심혈관 질환 위험 도는 모두 증가하고 통계적으로 유의한 선형관계가 입증되어 기존 연구결과와 일치한 반면, 남성의 경우는 GGT 2분위수에서 FRS와 10 년 심혈관 질환 위험도가 가장 높아 서로 다른 결과를 보였다. 여 기에서 성별에 따른 GGT 수준별 평균 연령을 살펴보면, 여성의 경 우 GGT 1분위수 수준에서 평균 연령이 46.6세, 4분위수 수준에서 평균 연령이 55.1세로 GGT 수준이 높아질수록 연령이 증가하였으 나, 남성의 경우 GGT 1 분위수 수준에서 평균 연령이 53.0 세, 2 분 위수에서 53.9세로 가장 높고 3 분위수에서 51.1세, 4분위수에서 51.4 세로 낮아졌음을 알 수 있다. 또한 연령에 따른 GGT 4분위수 별 분포에서 여성의 경우 30 대에 GGT 1분위수와 2 분위수의 비율 이 높고 70대에서 GGT 3분위수와 4분위수의 비율이 높아져서 연 령이 증가함에 따라 GGT의 수치가 증가한다는 여러 연구 결과와 분포가 일치한다[21-22]. 그러나 60대 이상 고령의 고혈당 환자 대 상의 연구에서는 60 대 보다 70 80대 환자의 GGT 수치가 더 낮게 나타나 연령 증가에 따라 감소하기도 하였다[23]. 또한 고도 음주자 를 제외한 선행 연구에서 중등도 음주자와 비음주자의 경우 연령 증가와 함께 70 세 이상의 고령에서는 음주빈도 및 음주량의 자연 적인 감소와 같은 사회적인 요인과 대사의 변화 등에 따라 연령과 GGT 수치가 음의 상관관계로 변화한다는 보고가 있다[24,25]. 이 러한 경향도 남성에 국한되어 나타났고 여성에서는 적용되지 않아 본 연구 결과와도 일치하였다. 본 연구에서 남성의 경우 70 대 고령 의 대상자들이 GGT 1, 2분위수에 많이 분포하여 GGT 2분위수의 평균 연령이 가장 높아졌으며 FRS와 10년 심혈관 질환 위험도 환산 에 연령 변수가 포함되므로 GGT 2분위수의 가장 높은 점수와 위험 도에 영향을 미친 것으로 볼 수 있다. 따라서 지금까지 GGT는 남녀 성별에 따른 차이만 주로 인식이 되어 있었고, 특히 지금까지의 연 구는 주로 연령이 증가함에 따라 GGT의 수치가 증가한다는 보고 가 더 많았으나 고령의 남성 대상자는 GGT 정상군 중에서도 낮은 수준에 속하는 경향이 나타나므로 연령에 따른 특성도 고려되어야 할 것이다.

본 연구에서 고도의 음주군에 해당하는 대상자를 모두 제외한 상태에서 GGT 수치가 정상 범위에 속하는 대상자만을 선정하였다 는 점에서 좀더 알코올에 대한 영향을 배제한 상태에서 관상동맥질 환 위험 요인과 GGT와의 관련성을 검증하였다는데 그 의미를 둘 수 있을 것이다. 하지만, 여성의 경우 심혈관 질환 발생에 영향을 준 다고 알려져 있는 폐경 여부에 대한 변수를 반영하지 못했고, 단면 연구이기에 GGT와 심혈관 질환과의 전후 관계를 입증하기는 어려
우므로 그 결과의 해석에는 한계가 있으나 혈중 GGT 수치가 정상 범위에 속하더라도 GGT 수치가 증가함에 따라 여러 위험인자와 관련성이 있음을 증명하였다. 한편 GGT 수치 증가와 함께 관상동 맥질환 관련 수치와 10년 위험도 관련 예측치 증가에 대한 부분은 연령과 성별에 따라 서로 다른 양상을 보였으므로 해석에 주의하여 야 하며 추후 GGT 관련 연구에서 고려해야 할 것으로 생각된다.

\section{요 약}

혈중 gamma-glutamyltransferase (GGT)는 지금까지 간기능 장애와 대표적인 알코올 섭취 관련 지표로서 폭넓게 사용되어 왔 다. 현재 다양한 질환과의 관련성이 밝혀지면서 그 관심이 커지고 있다. 본 연구에서는 고도의 음주군에 해당하는 대상자를 제외하고 GGT 수치가 정상 범위에 속하는 대상자들에서 GGT 수치에 따른 관상동맥 질환 위험 요인과의 관련성을 살펴보고, 연령과 성별에 따른 특성을 비교 검토 하였다. 분석 자료는 2011 국민건강영양조 사 데이터를 이용하였다(N=3,619). GGT(IU/L) 수준에 따라 사분 위수(quartile) 네 군으로 나누었을 때 GGT기준은 남성의 경우 순 서대로 10 20, 21 27, 28 38, 39 71 IU/L 이었고, 여성의 경 우 각각 $6 \sim 12,13 \sim 16,17 \sim 22,23 \sim 42 \mathrm{IU} / \mathrm{L}$ 였다. 대부분의 변수 에서 평균치는 GGT 4분위수로 갈수록 수치가 높게 나타났으나, 남 성에서 연령과 저밀도콜레스테롤은 GGT 2분위수에서 수치가 가 장 높았다. FRS와 10년 관상동맥 질환 위험도는 남성에서 GGT 2 분위수에서 유의하게 높았고, 여성의 경우 GGT 4분위수에서 유의 하게 높았다. 여성의 경우 GGT 수준이 높아질수록 연령이 증가하 였으나, 남성의 경우 GGT 2 분위수에서 가장 높았다. 연령 70 대에 서 남성의 경우 1,2 분위수 분포가 가장 많고, 여성의 경우 3,4 분위 수 분포가 많아 그 차이가 뚜렷하게 나타났다. GGT 수치가 정상 범 위에 속하더라도 GGT 수치가 증가함에 따라 여러 위험인자와 관 련성이 있음을 증명하였다. 그러나 GGT 수치 증가와 함께 관상동 맥질환 관련 수치와 10 년 위험도 관련 예측치 증가에 대한 부분은 연령과 성별에 따라 서로 다른 양상을 보였다.

\section{Acknowledgements: None \\ Funding: None \\ Conflict of interest: None}

\section{References}

1. Conigrave KM, Saunders JB, Reznik RB, Whitfield JB. Prediction of alcohol-related harm by laboratory test results. Clin Chem. 1993;39:2266-2270. 
2. Whitfield JB. Gamma-glutamyl transferase. Crit Rev Clin Lab Sci. 2001;38:263-355.

3. Lee DH, Blomhoff R, Jacobs DR Jr. Is serum gamma-glutamyltransferase a marker of oxidative stress? Free Radic Res. 2004;38:535-539.

4. Neuschwander-Tetri BA, Caldwell SH. Nonalcoholic steatohepatitis: summary of an AASLD single topic conference. Hepatology. 2003;37:1202-1219.

5. Pompella A, Emdin M, Passino C, Paolicchi A. The significance of serum $\gamma$-glutamyltransferase in cardiovascular diseases. Clin Chem Lab Med. 2004;42:1085-1091.

6. Paolicchi A, Emdin M, Ghliozeni E, Ciancia E, Passino C, Popoff G, Pompella A. Human atherosclerotic plaques contain gamma-glutamyl transpeptidase enzyme activity. Circulation. 2004;109:1440.

7. Emdin M, Passino C, Michelassi C, Titta F, L'Abbate A, Donato L, Pompella A, Paolicchi A. Prognostic value of serum gamma-glutamyl transferase activity after myocardial infarction. Eur Heart J. 2001;22:1802-1807.

8. Lee DH, Jacobs DR Jr, Gross M, Kiefe CI, Roseman J, Lewis CE, et al. Gamma-glutamyltransferase is a predictor of incident diabetes and hypertension: the coronary artery risk development in young adults (CARDIA) Study. Clin Chem. 2003; 49:1358-1366.

9. Rantala AO, Lilja M, Kauma H, Savolainen MJ, Reunanen A, Kesaniemi YA. $\gamma$-Glutamyl transpeptidase and the metabolic syndrome. J Intern Med. 2000;248:230-238.

10. Ryu S, Chang Y, Kim DI, Kim WS, Suh BS. Gamma-glutamyltransferase as a predictor of chronic kidney disease in nonhypertensive and nondiabetic Korean men. Clin Chem. 2007; 53:71-77.

11. Whitfield JB. Serum $\gamma$-Glutamyltransferase and risk of disease. Clin Chem. 2007;53:1-2.

12. Perry IJ, Wannamethee SG, Shaper AG: Prospective study of serum gamma-glutamyltransferase and risk of NIDDM. Diabetes Care.1998;21:732-737.

13. Kim KN, Kim KM, Lee DJ, Joo NS. Serum gamma-glutamyltransferase concentration correlates with framingham risk score in Koreans. J Korean Med Sci. 2011;26:1305-1309.

14. Chun HJ, Park SK, Ryoo JH. Association of serum $\gamma$-glutamyltransferase level and incident prehypertension in Korean men.J
Korean Med Sci. 2013;28:1603-1608.

15. Wilson PWF, D’ Agostino RB, Levy D, Belanger AM, Silbershatz H, Kannel WB. Prediction of coronary heart diseases using risk factor categories. Circulation. 1998;97:1837-1847.

16. Park WH, Chae SC, Chun BY, Lee KE, Kim BW, Kim JG, et al. Relationship between serum gamma-glutamyltransferase and metabolic syndrome among Korean non-diabetic adults. Korean J Epidemiol. 2008;30:206-215.

17. Lippi G, Targher G, Montagnana M, Salvagno GL. Relationship between $\gamma$-glutamyltransferase, lipids and lipoprotein(a) in the general population. Clin Chim Acta. 2007;384:1163-1166.

18. Kim DS, Sung HH, Cho EK, Lee JW. A study on the relationship between carotid artery intima-media thickness and clinical chemistry tests. Korean J Clin Lab Sci. 2015;47(4):188-193.

19. Ko HJ, Choi CS, Youn CH, Lee DH, Lee SG. The association between serum gamma-glutamyltransferase within normal range and risk factors of cardiovascular diseases: based on the framingham risk score. Korean J Obes. 2013;22(1):21-29.

20. Kim SH, Choi HR, Won CW, Kim BS. Optimal cutoff points of anthropometric parameters to identify high coronary heart disease risk in Korean adults. J Korean Med Sci. 2016;31:61-66.

21. Conigrave KM, Degenhardt LJ, Whitfield JB. Saunders JB, Helander A, Tabakoff B. CDT, GGT, and AST as markers of alcohol use: the WHO/ISBRA collaborative project. Alcohol Clin Exp Res. 2002;26:332-339.

22. Stromme JH, Rustad P, Steensland H. Theodorsen L, Urdal P. Reference intervals for eight enzymes in blood of adult females and males measured in accordance with the international federation of clinical chemistry reference system at 37 degrees C: part of the nordic reference interval project. Scand J Clin Lab Invest. 2004; 64:371-384.

23. Kim CH, Kim ES, Cho BC. Comparison of clinical biochemicals in sera of senior patients with hyperglycemia. Korean J Clin Lab Sci. 2012; $44(2): 46-51$.

24. Puukka K, Hietala J, Koivisto H, Anttila P, Bloigu R, Niemela O. Age-related changes on serum GGT activity and the assessment of ethanol intake. Alcohol Alcohol. 2006;41(5):522-527.

25. Karlamangla A, Zhou K, Reuben D. Greendale G, Moore A. Longitudinal trajectories of heavy drinking in adults in the United States of America. Addiction. 2006;101:91-99. 